\title{
KONSERVASI BAHAN GALIAN UPAYA PEMBANGUNAN BERBASIS GEOLOGI
}

\author{
Oleh : \\ Sabtanto Joko Suprapto \\ Kelompok Kerja Konservasi - PMG
}

\section{S A R I}

Pengembangan Subsektor pertambangan umum melalui pemanfaatan bahan galian merupakan bagian yang tak terpisahkan dari upaya pemenuhan kebutuhan dasar bagi pembangunan dan kehidupan manusia. Bahan galian sebagai sumber daya alam tak terbarukan terdapat dalam jumlah yang sangat terbatas, perlu dikelola secara baik agar dapat diperoleh manfaat yang optimal.

Konservasi bahan galian merupakan upaya untuk mendapatkan manfaat bahan galian secara optimal, berkelanjutan, berwawasan lingkungan serta dengan mencegah terabaikan dan tersia-siakannya potensi bahan galian. Bahan galian sebagai sumber daya geologi, memerlukan dukungan data geologi yang lengkap dan akurat untuk dasar penetapan dan pengelolaannya.

Sumber daya geologi berupa bahan galian umumnya berada di bawah permukaan, oleh karena itu potensi pemanfaatannya sangat tergantung pada status peruntukan wilayah/kawasan dalam tataruang daerah maupun nasional. Optimalisasi manfaat sumber daya geologi memerlukan aturan perundang-undangan agar potensi yang ada di permukaan maupun bawah permukaan dapat dikelola secara lebih optimal untuk kepentingan pembangunan masyarakat secara berkelanjutan.

\section{PENDAHULUAN}

Wilayah Indonesia berada pada lingkungan tektonik dimana terjadi pertemuan beberapa lempeng yang berpotensi membentuk kondisi geologi dengan kandungan cebakan bahan galian ekonomis disamping berpotensi juga terjadinya bencana. Potensi tersebut perlu diungkap agar dapat dipergunakan sebagai dasar dalam penetapan kebijakan arah pembangunan yang berlandaskan pada potensi sumber daya geologi suatu wilayah/kawasan.

Dalam pengelolaan sumber daya geologi yang berupa bahan galian mempunyai daya ubah lingkungan tinggi, leh karena itu dalam pemanfaatannya harus mempertimbangkan seluruh aspek yang dapat berdampak kurang menguntungkan bagi lingkungan.

Pengembangan suatu kawasan perlu mempertimbangkan seluruh potensi yang ada sehingga tidak ada potensi yang terabaikan. Upaya konservasi bahan galian bertujuan untuk mendapatkan manfaat yang optimal hanya akan dapat terlaksana dengan baik apabila didukung oleh data geologi yang memadai.

\section{KONSERVASI BAHAN GALIAN}

\section{Tinjauan Umum}

Pertambangan sebagai usaha pengambilan bahan galian yang bernilai ekonomis dan untuk dimanfaatkan dengan penggunaan yang tepat, dapat merupakan ujung tombak dalam pengembangan wilayah. Pengembangan sektor pertambangan merupakan bagian integral dari pembangunan nasional dalam rangka mewujudkan cita-cita bangsa mencapai masyarakat adil dan makmur. Hal ini merupakan perwujudan dari amanat Undang undang Dasar (UUD) 1945 Pasal 33, dimana pada hakikatnya adalah upaya pengembangan sumber daya alam bahan galian yang potensial untuk dapat dimanfaatkan secara optimal bagi kepentingan dan kemakmuran rakyat.

Sektor pertambangan mempunyai nilai strategis, sebagai penyedia bahan baku pembangunan fisik dan industri di dalam negeri, penghasil devisa negara melalui ekspor maupun sebagai pendukung pengembangan wilayah terutama untuk daerah terpencil. Pengembangan sektor pertambangan perlu diarahkan untuk mendorong kegiatan ekonomi dengan mempertimbangkan prinsip lahan berganda dan tata 
ruang yang mengacu kepada kebijakan nasional melalui kebijaksanaan optimasi manfaat dan pendayagunaan kekayaan alam.

Pengelolaan bahan galian diarahkan untuk peningkatan kesejahteraan rakyat dengan pertimbangan berdasarkan prinsip keberlanjutan pembangunan nasional di masa mendatang dengan melaksanakan konservasi bahan galian, untuk mendapatkan manfaat yang optimal dari sumber daya bahan galian.

Terciptanya keseimbangan antara pemanfaatan dan kelestarian sumber daya alam dan lingkungan hidup, merupakan prasyarat penting bagi terlaksananya pembangunan sumber daya bahan galian yang berkelanjutan. Pemanfaatan sumber daya bahan galian yang terkendali dan berwawasan lingkungan akan menjadi salah satu modal dasar yang sangat penting bagi pembangunan nasional secara keseluruhan. Selain itu ketersediaan sumber daya bahan galian juga mampu memberikan sumbangan yang cukup berarti bagi pembangunan ekonomi dan penyerapan tenaga kerja.

Pengelolaan sumber daya bahan galian harus senantiasa memberi kemanfaatan masa kini juga harus menjamin kehidupan masa depan. Oleh karena itu pendayagunaan sumber daya bahan galian untuk kemakmuran rakyat harus dilakukan secara terencana, lasional, optimal, bertanggung jawab dan sesuai dengan kemampuan daya dukungnya serta mengutamakan sebesar-besar kemakmuran rakyat dan pembangunan nasional.

Pembangunan sektor pertambangan diantaranya adalah melalui pengembangan sumber daya alam tak terbarukan, yang menempati sebaran ruang tertentu di dalam bumi dan dasar laut, dalam jumlah yang terbatas, pengusahaannya melibatkan investasi dan kegiatan yang sarat resiko, padat modal dan teknologi, serta proses penambangannya memiliki potensi daya ubah lingkungan yang tinggi.

Dengan adanya berbagai ciri khusus bahan galian dan minat para pengusaha pertambangan serta kendala, tuntutan dan tantangannya, maka pengelolaan bahan galian harus dilakukan secara sungat seksama dan dimulai sejak awal, melibatkan berbagai pihak terutama dalam penataan lahan pembangunan sampai dengan pemanfaatan bahan galian. Oleh karena itu, pengelolaan bahan galian harus sepenuhnya menerapkan kaidah konservasi bahan galian. Tanpa penerapan prinsip konservasi secara intensif dan efektif dalam kegiatannya maka pembangunan sektor pertambangan dapat tersendat dan sekaligus dapat menyebabkan menurunnya peran dan manfaat sumber daya bahan galian tersebul akibat hilangnya kesempatan untuk diusahakan ataupun terbuangnya nilai bahan galian, baik secara fisik, ekonomis maupun fungsinya.

\section{Ruang Lingkup}

Ruang lingkup konservasi bahan galian meliputi tahapan hulu sampai dengan hilir kegiatan sektor pertambangan. Dalam upaya untuk mewujudkan optimalisasi manfaat harus dilakukan mulai dari penetapan kawasan, perizinan, tahapan kegiatan penyelidikan umum, eksplorasi, penetapan sumber daya dan cadangan, recovery penambangan, stripping ratio, cut off greale, penanganan bahan galian kadar marjinal dan kadar rendah, recovery pengangkutan, pengolahan dan pemurnian, penanganan mineral ikutan dan bahan galian lain, sisa sumber daya dan cadangan pasca tambang, tailing, peningkatan nilai tambah bahan galian, sampai dengan penutupan tambang dan penataan wilayah konservasi pertambangan umum.

Optimalisasi manfaat sebagai tujuan konservasi bahan galian tidak mengarah pada upaya pelestarian bahan galian mineral. Penyia-nyiaan bahan galian dihindari dalam pengertian bahwa seminimal mungkin potensi bahan galian yang tidak termanfaatkan dan tidak terjadi degradasi nilai maupun kuantitas potensi bahan galian sebagai akibat pengelolaan yang tidak optimal.

Pengelolaan tidak optimal dapat terjadi pada kegiatan usaha pertambangan maupun sebagai akibat peraturan dan kebijakan yang menyebabkan tidak memungkinkannya potensi bahan galian dapat dimanfaatkan secara optimal. Selain itu dapat terjadi juga sebagai akibat data geologi yang ada tidak mengungkap seluruh potensi pada suatu wilayah, sehingga menyebabkan terabaikannya sebagian potensi bahan galian.

Pengaturan pengelolaan bahan galian dimulai dengan penataan kawasan/wilayah pertambangan dan perizinannya, pengaturan jenis, jumlah, kualitas bahan galian, proses pertambangan, penggunaan bahan galian, sampai dengan sistem pungutan. Sementara faktor yang mempengaruhi upaya optimalisasi pemanfaatan bahan galian antara lain adalah waktu. 
jenis, jumlah, kualitas, lokasi dan posisi keterdapatan serta proses pengolahan sesuai dengan kemajuan teknologi dan modal yang tersedia berupa materi maupun sumberdaya manusia.

\section{PERANAN GEOLOGI DALAM PENERAPAN KONSERVASI BAHAN GALIAN}

Bahan galian sebagai karunia Tuhan Yang Maha Esa merupakan sumber daya alam yang tak terbarukan sehingga pengelolaannya harus diwujudkan secara bijaksana, efektif dan efisien agar diperoleh manfaat yang optimal dan berkelanjutan bagi kepentingan rakyat secara luas.

Bahan galian sebagai bagian dari sumber daya geologi, memerlukan langkah pengelolaan yang sistematis oleh pemerintah dan pelaku usaha pertambangan mulai dari perumusan kebijakan berupa penetapan peraturan perundang-undangannya sampai dengan pemanfaatannya.

\section{Perumusan Kebijakan}

Pemanfaatan bahan galian dengan mengupayakan terciptanya keseimbangan antara pemanfaatan dan kelestarian sumber daya alam dan lingkungan hidup, merupakan prasyarat penting bagi keberlanjutan pembangunan. Kerusakan lingkungan diusahakan seminimal mungkin, dengan pengertian bahwa degradasi potensi bahan galian juga dihindari, yaitu turunnya atau hilangnya nilai bahan galian sebagai akibat kebijakan atau peraturan perundang-undangan yang menyebabkan tidak bisa termanfaatkan atau turunnya nilai bahan galian akibat pengelolaan yang tidak optimal.

Peraturan perundang-undangan yang mewajibkan bagi pengelola sumber daya alam agar selalu mempertimbangkan potensi sumber daya geologi berupa bahan galian sangat diperlukan.

Sebagai bagian dari sumber daya alam, bahan galian mempunyai peranan dan fungsi sejajar dengan sumber daya alam yang lain. Sehingga konservasi terhadap sumber daya alam yang lain pada suatu wilayah/kawasan dilaksanakan dengan tidak mengabaikan kandungan bahan galiannya.

\section{Penetapan Kawasan}

Upaya pemanfaatan potensi bahan galian terkait sangat erat dengan ketetapan tentang peruntukan suatu kawasan atau wilayah. Penetapan kawasan atau wilayah harus selalu mempertimbangkan keberadaan sumber daya geologi dan potensi bencana geologi. Mengingat penetapan peruntukan kawasan mempunyai implikasi hukum terhadap pemanfaatan sumber daya geologi, maka diperlukan kajian yang mendalam dengan dilatarbelakangi data dasar tentang potensi sumber daya dan sumber bencana yang lengkap dan akurat, sehingga menghasilkan ketetapan yang paling menguntungkan bagi kepentingan masyarakat.

Penetapan peruntukan kawasan/ wilayah melibatkan beberapa disiplin ilmu dan tumpang tindih kepentingan beberapa sektor, oleh karena itu diperlukan kebijakan yang mampu mengakomodasi sektor-sektor terkait untuk mendapatkan hasil yang paling menguntungkan bagi masyarakat secara keseluruhan.

Kawasan berpotensi sumber daya geologi, khususnya yang mengandung cebakan bahan galian/mineral primer umumnya berada pada daerah tinggian dengan morfologi ekstrim. Kawasan dengan kondisi tersebut akan cenderung ditetapkan sebagai kawasan hutan konservasi atau hutan lindung, walaupun pada daerah terdapatnya endapan logam primer umumnya merupakan lahan tandus (Gambar 1). Kasus di Pulau Sumatera dapat dijadikan contoh, dimana berdasarkan hasil asesmen sumber daya tembaga-emas porfiri seluruh Pulau Sumatera (Tain dkk 2005) potensi sumber daya bijih tembaga-emas porfiri sebesar 6.120.367.000 ton dan mempunyai korelasi positip terhadap potensi cebakan bijih perak. Berdasarkan track endapan tembaga-emas porfiri (Gambar 2) potensi bijih tembaga-emas porfiri berada memanjang mengikuti daerah Bukit Barisan, yang umumnya telah ditetapkan sebagai kawasan hutan konservasi dan hutan lindung.

Endapan tembaga-emas tipe porfiri umumnya membentuk cebakan dalam dimensi besar dengan kadar rendah, sehingga hanya layak ditambang dengan sitem terbuka. Mengingat undang-undang nomor 41 tahun 1999 melarang adanya penambangan secara terbuka pada kawasan hutan lindung, maka potensi bahan galian yang berada pada kawasan tersebut menjadi tidak mempunyai nilai ekonomi.

\section{Perizinan}

Perizinan yang dikeluarkan untuk usaha pertambangan akan mempunyai konsekuensi terhadap upaya konservasi bahan galian. Pengeluaran izin mempertimbangkan seluruh potensi bahan galian yang 
eologi.

wasan

faatan

yang

entang

yang

etapan

tingan

rilayah tindih

a itu

modasi

l yang

secara

eologi,

bahan

daerah

dengan

sebagai

indung,

logam

Gambar

contoh,

$r$ daya

a (Tain

ra-emas

ipunyai

i perak.

polfiri

berada

I, yang

1 hutan

rumnya dengan ambang -undang ibangan

; maka iawasan ni.

usaha erhadap an izin an yang ada, sehingga nantinya tidak ada potensi bahan galian yang terabaikan atau tersia-siakan. Untuk itu maka diperlukan pemahaman dan pengetahuan tentang keterjadian sumber daya bahan galian serta kelengkapan informasi yang berkaitan dengan seluruh potensi sumber daya bahan galian pada suatu wilayah usaha pertambangan.



Gambar 1.

Endapan bijih emas pada puncak bukit, kawasan cagaralam burung maleo, Kabupaten Pohuwato

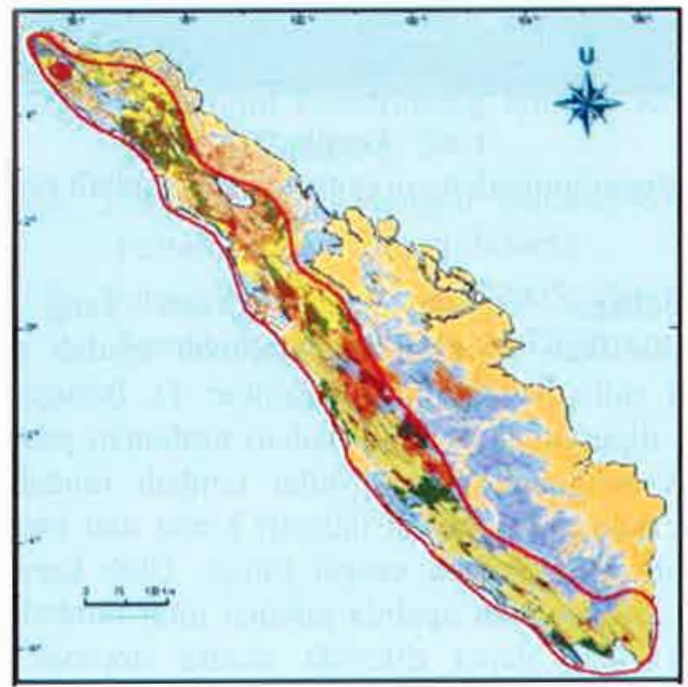

Gambar 2.

Peta track endapan $\mathrm{Cu}-\mathrm{Au}$

\section{Eksplorasi}

Upaya konservasi bahan galian dalam penerapannya tidak hanya menangani sisi hilir dari kegiatan pertambangan, namun untuk memperoleh manfaat yang optimal, bahan galian harus dikelola dengan baik mulai dari hulu sampai hilir. Pada kegiatan usaha pertambangan, sejak eksplorasi sudah harus berorientasi menerapkan kaidah konservasi bahan galian dengan pengumpulan data seoptimal mungkin, sehingga dalam kegiatan pertambangan selanjutnya didukung oleh data lengkap sebagai dasar perencanaan penerapan konservasi bahan galian. Dengan demikian tidak ada potensi bahan galian yang terabaikan sebagai akibat tidak lengkapnya data.

Eksplorasi yang dilakukan oleh para pelaku usaha pertambangan umumnya mempunyai target yang berbeda terhadap jenis maupun dimensi bahan galian yang akan diusahakan. Pelaku usaha pertambangan dengan target jenis bahan galian tertentu diwajibkan untuk melaporkan data bahan galian lain dan mineral ikutan yang berada pada wilayah usaha pertambangannya, agar saat kegiatan penambangan dan pengolahan nantinya dapat digunakan sebagai data dasar dalam melakukan penanganan.

Pelaku usaha pertambangan sekala besar cenderung akan mengusahakan bahan galian yang berdimensi besar. Daerah relinguished, yaitu wilayah yang telah diserahkan kembali kepada pemerintah oleh pihak pelaku usaha pertambangan dimana setelah melalui proses eksplorasi dan evaluasi dianggap sebagai wilayah tidak prospektif untuk komoditas bahan galian yang akan dieksploitasi dalam sekala usahanya, yaitu akibat tidak ditemukannya endapan dalam jumlah sumber daya yang besar. Wilayah yang telah ditinggalkan tersebut masih mungkin memiliki potensi untuk komoditas mineral yang sama tetapi dalam sekala penambangan yang lebih kecil atau dalam bentuk metoda penambangan dan pengolahan yang berbeda. Daerah tersebut juga mungkin dapat memiliki potensi untuk usaha tambang komoditas mineral lainnya yang sebelumnya tidak menjadi target ekplorasi. Oleh karena itu data geologi hasil kegiatan eksplorasi menjadi dasar penting penilaian atas potensi bahan galiannya.

\section{Penambangan dan Pengolahan}

Kegiatan penambangan dan pengolahan memerlukan sistematika dan teknologi yang tepat 
guna sesuai dengan kondisi dan tipe endapannya, sehingga tingkat perolehan bahan galian dapat optimal.

Pengelolaan bahan galian untuk mendapatkan manfaat yang optimal pada kenyataannya menemui banyak kendala, antara lain disebabkan oleh keterbatasan operasional penambangan dan pengolahan sehingga dapat menyebabkan tertinggal dan terbuangnya bahan galian (Gambar 3). Oleh karena itu data kondisi geologi tentang bahan galian berpotensi tertinggal maupun bahan galian berpotensi terbuang, meliputi bahan galian utama, mineral ikutan dan bahan galian lain yang belum dimanfaatkan, baik yang belum atau sudah ditambang, perlu diinventarisir sebagai dasar evaluasi untuk mencegah menurun atau hilangnya nilai ekonomi bahan galian dan untuk meminimalkan atau mencegah terbuangnya bahan galian.

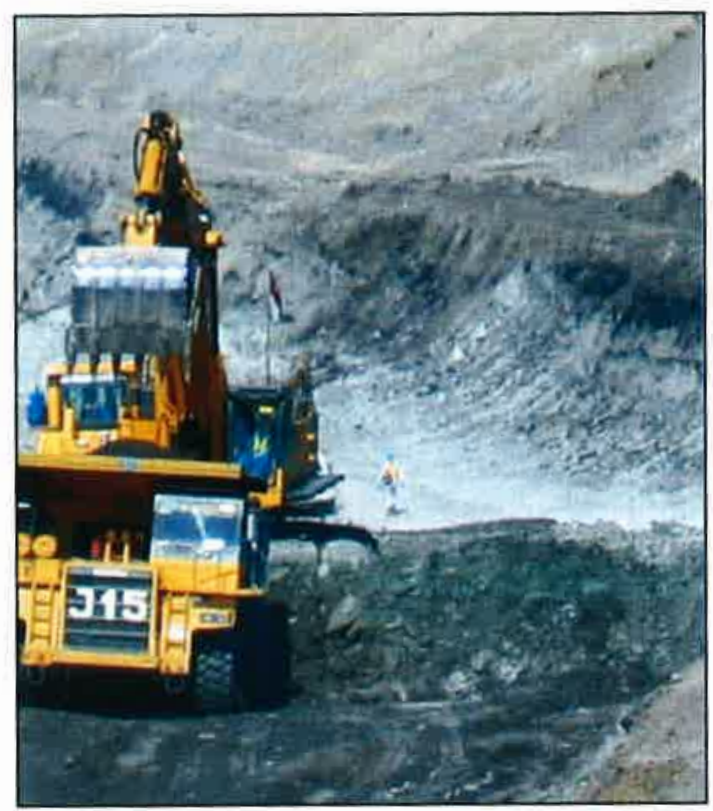

Gambar 3.

Lapisan bentonit (warna putih) pada tambang batubara diperlakukan sebagai waste

Pada pelaksanaan penambangan tidak semua bahan galian dimanfaatkan yaitu antara lain bahan galian kadar/kualitas rendah, marginal dan mineral ikutan, sehingga dianggap waste atau tailing. Untuk mengantisipasi kecenderungan harga dan permintaan komoditas bahan galian yang sewaktu-waktu dapat berubah maka perlu penanganan antara lain dapat dengan menimbun di lokasi tertentu dan melakukan penanganan tertentu agar tidak mencemari lingkungan dan terkontaminasi, serta nantinya dapat ditambang kembali dengan mudah.

\section{Nilai Tambah}

Sebagai sumber daya tak terbarui, bahan galian dengan sifat kimia dan fisika tertentu memungkinkan untuk dipergunakan bagi beberapa alternatif pemanfaatan dengan tingkatan nilai tambah rendah sampai dengan tinggi. Mengingat ketersediaannya di alam yang terbatas, maka penetapan pemanfaatan/peruntukan bahan galian harus dilakukan secara tepat agar manfaat yang didapatkan menghasilkan nilai tambah optimal. Penetapan peruntukan bahan galian dapat dilakukan pada saat pemberian izin, dengan berdasarkan antara lain pada data kuantitas dan kualitas bahan galian.



Gambar 4.

Batugamping dengan potensi nilai tambah tinggi

Sebagai contoh bahan galian yang dapal menghasilkan potensi nilai tambah rendah sampai tinggi yaitu batugamping (Gambar 4). Batugamping dapat dipergunakan untuk bahan timbunan jalan atau bahan bangunan dengan nilai tambah rendah atau dapat pula untuk bahan industri kimia dan metalurgi dengan nilai tambah sangat tinggi. Oleh karena itu patut disayangkan apabila potensi nilai tambah yang tinggi tidak dapat dikelola secara optimal. Nilai tambah tinggi diupayakan tidak hanya dari satu macam produk hasil pengolahan/ penggunaan bahan galian, akan tetapi dapat berasal dari efek ganda rangkaian beberapa peruntukan secara berkesinambungan sehingga dapat menghasilkan nilai tambah berganda. 
